ORIGINAL

\title{
¿Podemos predecir el uso de psicoestimulantes en jóvenes? Un estudio a partir de un modelo de ecuaciones estructurales.
}

\section{Can we predict psychostimulant use in youths? A study with structural equation modeling analysis}

\author{
Elisardo Becoña*; Ana López-DURán*; \\ Elena Fernández del Río*; Úrsula Martínez ; \\ Jaime Fraga ${ }^{\star \star}$; Jesús Osorio*; Manuel Arrojo*; \\ Fernanda López-Crecente ${ }^{\star \star}$; María Nieves Domínguez ${ }^{\star \star}$
}

* University of Santiago de Compostela, Faculty of Psychology, Department of Clinical Psychology and Psychobiology, Santiago de Compostela, Galicia, Spain.

** Dirección de Asistencia Sanitaria. Servicio Galego de Saúde, Santiago de Compostela, Galicia, Spain.
Correspondence can be sent to:

Elisardo Becoña.

Department of Clinical Psychology and Psychobiology.

Faculty of Psychology. University of Santiago de Compostela.

15782 Santiago de Compostela. Galicia. Spain.

E-mail: elisardo.becona@usc.es

\section{Resumen}

Conocer qué factores predicen el consumo de psicoestimulantes en jóvenes es importante para el diseño de programas preventivos y para identificar a los jóvenes que tienen una mayor probabilidad de consumir y asi evitar que aparezcan los problemas derivados de dicho consumo. El objetivo de este estudio fue analizar la relación entre la disponibilidad percibida, la percepción de riesgo, los rasgos de personalidad, los patrones de personalidad antisocial y el consumo de otras sustancias en la predicción del consumo de psicoestimulantes. La muestra estuvo formada por 1.177 jóvenes (584 varones y 593 mujeres) de entre 14 y 25 años en España, reclutados aleatoriamente, estratificados por consumo-no consumo de psicoestimulantes (cocaina o éxtasis) alguna vez en la vida. El path que mejor predijo el consumo de psicoestimulantes fue: rasgos de personalidad-patrones de personalidad antisocial- consumo de psicoestimulantes. El siguiente path fue: rasgos de personaliad- patrones de personalidad antisocial-consumo de psicoestimulantes. La percepción de riesgo y la disponibilidad percibida fueron significativas en la predicción pero aportaron una contribución menor. Los resultados de este estudio sugieren que el modelo evaluado es adecuado para la predicción del consumo de psicoestimulantes en jóvenes. Este modelo puede ser de utilidad para desarrollar estrategias preventivas y para identificar a aquellos jóvenes con riesgo de tener problemas relacionados con el consumo de drogas.

Palabras clave: psicoestimulantes, jóvenes, disponibilidad percibida, percepción de riesgo, personalidad, impulsividad, búsqueda de sensaciones.

\section{Abstract}

Knowing which factors predict the use of psychostimulant drugs among youths is important for designing preventive programs and the identification of youths with the highest probability of use, to avoid some of the problems that can be derived from it. The purpose of this study is to examine the relationship between perceived availability, risk perception, personality traits, antisocial personality patterns, and use of other substances in the prediction of psychostimulant use. The sample was composed by 1,177 youths (584 males and 593 females) aged 14 to 25 in Spain, recruited randomly, stratified by lifetime use- non use of psychostimulants (cocaine or ecstasy). The path which best predicts psychostimulant use is: Personality traits-legal substance use-cannabis use-psychostimulant use. The next path is: Personality traits-antisocial personality patterns-psychostimulant use. Risk perception and perceived availability were significant in the prediction, but made a smaller contribution. The results of this study suggest that the model evaluated can predict psychostimulant use in youths. This model can be seen as a useful tool for developing preventive strategies and for identifying those youths that are at risk for problems related to drug use.

Key words: Psychostimulants, youths, perceived availability, risk perception, personality, impulsiveness, sensation-seeking. 
$\mathrm{T}$ he use of psychostimulant drugs among youths has negative consequences for health (Steinberg, 2010; Sussman, Skara, \& Ames, 2008). Knowing which factors predict such use (and the relationship between them) is important for designing preventive programs and the identification of youths with the highest probability of use, to avoid some of the problems that derived from it.

Different risk and protection factors associated with the use of drugs have been analyzed, individually and interpersonally (Hawkins, Catalano, \& Miller, 1992; Calafat et al., 2010). To a lesser extent, research has looked at the relationships between them and the way in which they predict the use of psychoactive substances. In the present study we explore the relationship between impulsiveness, sensation-seeking, perceived availability of psychostimulants, risk perception of psychostimulants, antisocial personality patterns, and use of other psychoactive substances (tobacco, alcohol, and cannabis), with the aim of predicting lifetime psychostimulant use (cocaine and ecstasy).

\section{Risk perception}

We know that the perception of risk about a substance is important for making decisions about using it. The level of risk perceived by youths about different drugs influences their use: The greater is the perception of risk about the use of a drug, the less is its use, and viceversa (Bachman, Johnston, O'Malley, \& Humphrey, 1988; Kilmer, Hunt, Lee, \& Neighbors, 2007; Leung, Ben Abdallah, Copeland, \& Cottler, 2010). For example, in the late 1970s in the USA the perceived risk of marijuana use was low and levels of use were high; later, the perceived risk increased and levels of use decreased, a situation that lasted until the early 1990s. However, from around 1992, levels of perceived risk fell again and use of the drug increased, until recent years when use levels are decreasing (Bachman, O'Malley, Schulenberg, Johnston, Freedman-Doan, \& Messermith, 2008). This finding has led to a change in the messages from authorities in different countries about the prevention of drug use.

\section{Perceived availability}

Regarding perceived availability, we know that the more accessible a substance is, the greater is its probability of use (Degendhart et al., 2008).

\section{Personality traits: Impulsiviness and sensation- seeking}

The study of impulsiveness and sensation-seeking, as personality traits that are risk or vulnerability factors for drug use, has an extensive support (Kubicka, Matejcek, Dytrych, \& Roth, 2001; Palmer, Montaño, \& Calafat, 2000; Verheul \& Van den Brink, 2000). Research shows that there is a clear relationship between impulsiveness and drug use. High levels of impulsiveness at early ages is related to earlier drug use and to drug-use problems in adulthood (Dawe, Gullo, \& Loxton, 2004; Forcada, Pardo, \& Bondía, 2006; Tarter et al., 2003; Von Diemen, García, Costa, Maciel,
\& Pechansky, 2008; Verdejo-García, Lawrence, \& Clark, 2008). On the other hand, sensation-seeking, defined as the individual's need for new, complex, and varied experiences and sensations, together with the desire to take physical and social risks to satisfy that need (Zuckerman, 1979), is associated with drug use (Fergusson, Boden, \& Horwood, 2008; Kahler, Read, Wood, \& Palfai, 2003; Martins, Storr, Alexandre, \& Chilcoat, 2008).

Regarding the relationship between sensation seeking and impulsiveness and drug use, Belin, Mar, Dalley, Robbins, \& Everitt (2008) suggest that sensation-seeking determines whether or not one begins using drugs, whilst impulsiveness would be responsible for the maintenance of use, and hence for the emergence of abuse and dependence problems.

\section{Antisocial personality patterns}

The relationship between drug use and personality disorders has been widely studied, given the high prevalence of these types of disorders among those seeking treatment for drug use. Most studies note that antisocial personality disorders (characterized by impulsiveness) are the most common in drug dependents in treatment (Chabrol, Ducongé, Casas, Roura, \& Carey, 2005; Cohen, Chen, Crawford, Brook, \& Gordon, 2007; Fantin, 2006; Keyes, Martins, \& Hasin, 2008; Korhonen et al., 2008; López \& Becoña, 2006a); Taylor, 2005. Moreover, the presence of these personality disorders in drug users has a negative influence on their treatment: They use illegal substances more frequently, they display a more harmful pattern of alcohol use, they are more compulsive, and they present more psychopathological problems, greater impulsiveness, less satisfaction with their lives and a greater isolation (Nace, Davis, \& Gaspari, 1991).

In youths, the presence of so-called antisocial syndromes (conduct disorder, antisocial behavior, and antisocial personality disorder in adulthood) is highly related to drug use (Becoña et al., 2011; Dierker, Vesel, Sledjeski, Costello, \& Perrine, 2007). Also, the presence of conduct disorder at age 13 years predicts substace use in adulthood (Cohen et al., 2007).

\section{Alcohol, tobacco, and cannabis}

Nowadays, drug use among youths is characterized by poly-drug use (Chung \& Martin, 2011; Johnston, O'Malley, Bachman, \& Schulenberg, 2009; Observatorio Español sobre Drogas, 2009). It is closely related to the transition to the use of other drugs and, as the Gateway Hypothesis suggests, drug use begins with legal drugs (alcohol and tobacco) and continues with illegal drugs (Kandel \& Faust, 1975; Kandel, 2002). Therefore, we should consider the previous use of other substances, such as tobacco, alcohol and cannabis to explain psychostimulant use.

In the present study, our objective is to test a model that explores the impact of personality traits, perceived availability, risk perception, antisocial personality patterns, legal substances, and cannabis on psychostimulant use/non- 
use in youths using structural equation modeling (SEM). In particular, we hypothesize that:

1) Sensation-seeking and impulsiveness are related to drug use (Martins et al., 2008; Verdejo-Garcia et al., 2008; Von Diemen et al., 2008), so that they predict the use of tobacco, drunkenness, and cannabis and that the use of these substances predicts psychostimulant use (cocaine and ecstasy). In the case of alcohol use we have considered as a variable the incidence of drunkenness due to frequent and normative drinking within Mediterranean culture (Observatorio Español sobre Drogas, 2009).

2) Sensation-seeking and impulsiveness are personality traits that characterize certain personality patterns, such as antisocial (American Psychiatric Association, 2000; Millon \& Davis, 1998), so that the presence of impulsiveness and sensation-seeking predicts antisocial personality pattern, which in turn predicts psychostimulant use (cocaine and ecstasy).

3) Perceived availability (Degenhardt et al., 2008) and perceived risk of psychostimulant use (Leung et al., 2010) also predict the use of these substances, so that high perceived availability and low perceived risk associated with psychostimulant use predict their use.

\section{Method}

\section{Participants}

We selected a representative sample of 1,214 youths aged 14 to 25 from seven cities in Galicia (Spain). The sampling was random, stratified by cities, age (14-17, 18-21 and 22-25), gender (male, female), and lifetime use or non use of psychostimulants (cocaine and ecstasy), with personal interviews in households and in leisure and recreational venues, to ensure adequate representativeness of psychostimulant use versus non-use.

Of the 1,214 participants, 1,177 had completed all measures: 584 were males (49.6\%) and 593 were females $(50.4 \%)$. Mean age of the sample was 19.65 years (SD $=3.13)$. Fifty per cent $(n=590)$ presented lifetime use of psychostimulants (cocaine and/or ecstasy) [33.8\% $(n=398)$ had lifetime use of ecstasy and $44.4 \%$ of cocaine ( $n=522)$ ]. Regarding use in the last year, $48.2 \%$ of the sample had used psychostimulants in the last year $[22.5 \%(n=265)$ had used ecstasy and $32.7 \%(n=385)$ had used cocaine].

Percentage of rejections for the total sample was $31.5 \%$.

\section{Measures}

Assessment of substance use was carried out by the following items: Psychostimulant use (Have you taken cocaine at any time in your life?; Have you taken ecstasy at any time in your life?), tobacco use (Have you smoked cigarettes at any time in your life?) cannabis use (Have you used cannabis at any time in your life?), and high levels of alcohol use (drunkenness; Have you ever been drunk?).
Assessment of perceived availability of cocaine and ecstasy and the perceived risk associated with the occasional use of cocaine and ecstasy was carried out using items from the study by Johnston, O'Malley, and Bachman (2001) [e.g., How difficult do you think it would be for you to get cocaine, if you wanted some? (answer categories were: Probable impossible, very difficult, fairly difficult, fairly easy, and very easy); How much do you think people risk harming themselves (physically or in other ways) if they try cocaine once or twice (answer categories were: No risk, slight risk, moderate risk, great risk, and can't stay, drug unfamiliar)].

Sensation-seeking was assessed by means of the Sensation Seeking Scale V (SSS-V; Zuckerman, 1979, 2007). It is a questionnaire of 40 items with dichotomous response format consisting of four subscales with ten items each: Thrill and Adventure Seeking, Experience Seeking, Disinhibition, and Boredom Susceptibility. The reliability of the SSS-V (Spanish version) was 0.77 (Perez \& Torrubia, 1986).

Impulsiveness was assessed with the Barratt Impulsiveness Scale- 11 (BIS- 11; Patton, Stanford, \& Barratt, 1995). It is a 30-item questionnaire with four response options. The items are grouped into three subscales: Attentional, motor, and nonplanning. Patton et al. (1995) reported internal consistency coefficients for the BIS-11 total score that range from 0.79 to 0.83 . We utilized the Spanish adaptation of Oquenda et al. (2001).

Pattern disorders were assessed in those youths aged 18 to 25 with the Millon Clinical Multiaxial Inventory III (MCMI-III; Millon, 1994); those youths aged 14 to 17 were administered the Millon Adolescent Clinical Inventory (MACl; Millon, Millon, Davis \& Grossman, 1997), which assesses personality patterns, and with scales that are equivalent to those of the MCMI-III. With both questionnaires we assessed: Antisocial and aggressive pattern of personality (antisocial personality pattern is assessed with the Antisocial personality scale of MCMI-III and with the Unruly personality scale in $\mathrm{MACl}$ while the Aggressive personality pattern is assessed with the Sadistic scale of the MCMI-III and with the Forceful scale of the $\mathrm{MACl}$ ). Aggressive personality pattern is considered by Millon and Davis (1998) as a subtype of antisocial personality pattern.

\section{Procedure}

This is a cross-sectional community-based epidemiological study in youths aged 14 to 25 . It was carried out using random sampling, and the interviews were administered at respondents' households and in leisure/ recreational venues of each city to guarantee adequate representativeness of lifetime use versus non-use of psychostimulants. Once we had obtained the non-users, and one part of users in households, the sample was completed in leisure and recreational venues, seeking people who ever used psychostimulants.

For the sampling, in the case of those interviewed at home, we randomly selected the streets in which the study would be carried out in each city, according to its number of inhabitants. In each street the number of interviews that 
could be administered was limited. The interviewers had to locate people aged 14 to 25 who lived in those streets (they had to be living in that city for at least 6 months), inform them about the objective of the study, and obtain their informed consent to be included in it. In the case of those youths under 18 it was necessary to obtain consent from a parent or guardian to fill out the questionnaire. In the case of leisure/recreational venues, sample selection was random among those youths who used stimulants.

All the interviews were personal, and carried out by specially trained staff (psychologists). In all cases, those youths proposed as participants gave their informed consent. The Clinical Research Ethics Committee of the Galician Regional Government (Xunta de Galicia) gave its authorization for the present study.

\section{Analysis strategy}

To examine hypothesized associations between variables (Figure 1) we used SEM with Amos 19 statistical modeling software (SPSS, 2006). SEM allows us to test the relations of all variables and underlying constructs simultaneously. The major advantages of this approach are the ability to identify direct and indirect effects and the corresponding standard errors, examine the associations among multiple independent and dependent variables in the model simultaneously, and obtain indices of overall model fit.

The aim was assessing the complete model made up of all the variables used in this study: Personality traits (sensationseeking and impulsiveness), perceived availability of cocaine and ecstasy, perception of risk involved in sporadic use of cocaine and ecstasy, legal substance use (tobacco and drunkenness), cannabis use and antisocial personality patterns (antisocial and aggressive personality patterns).
We used the maximum-likelihood method (Byrne, 2010) and three types of indices for rating the quality of the analysis: (1) Measures of absolute fit, such as the chi-squared statistic, the Goodness-of-Fit Index (GFI) and the Root Mean Square Error of Approximation (RMSEA); (2) measures of incremental fit, that is, the comparative fit with respect to the baseline model using the Adjusted Goodness-of-Fit Index (AGFI); and (3) measures of the model's parsimony, using the Comparative Fit Index (CFI). In general, a model is considered to show good fit when chi-squared permits the acceptance of the null hypothesis in the fit to the data in small samples, the RMSEA is not higher than 0.10 (or more restrictively, than 0.08), and the GFI, CFI and AGFI approach 1 (Byrne, 2010; Ruiz, Pardo, \& San Martín, 2010; SPSS, 2006).

\section{Results}

Bivariate correlations among all measured variables are presented in table 1.

Results of the structural equation modeling analysis indicated that the fit was adequate, since all the indices exceeded the minimum acceptance level, except for the chisquared statistic: $\chi^{2} /$ d.f. $=5.381 ; \mathrm{CFI}=0.960 ; \mathrm{GFI}=0.961$; RMSEA $=0.061 ; A G F I=0.936$ (Table 2). The fact that $\chi^{2} /$ d.f. is so high may be because it is a statistic highly sensitive to sample size, so that with large samples (over 200 cases) it is easy to reject the null hypothesis when the model achieves good fit (SPSS, 2006; Tabachnick \& Fidell, 2007).

All the relationships between factors were significant. As we can see in Figure 1, the latent variables provided a good explanation for their corresponding observable variables, since all the coefficients were above 0.70 , with the exception of sensation-seeking, with a coefficient

Table 1. Bivariate correlations among all measured variables.

\begin{tabular}{|c|c|c|c|c|c|c|c|c|c|c|c|c|}
\hline & Drunkenness & $\begin{array}{c}\text { Tobacco } \\
\text { use }\end{array}$ & $\begin{array}{c}\text { Cannabis } \\
\text { use }\end{array}$ & $\begin{array}{c}\text { Ecstasy } \\
\text { use }\end{array}$ & $\begin{array}{c}\text { Cocaine } \\
\text { use }\end{array}$ & $\begin{array}{l}\text { Perceived } \\
\text { availability } \\
\text { of cocaine }\end{array}$ & $\begin{array}{l}\text { Perceived } \\
\text { availability } \\
\text { of ecstasy }\end{array}$ & $\begin{array}{c}\text { Risk of } \\
\text { cocaine } \\
\text { use }\end{array}$ & $\begin{array}{c}\text { Risk of } \\
\text { ecstasy } \\
\text { use }\end{array}$ & Impulsiveness & $\begin{array}{l}\text { Sensation } \\
\text { seeking }\end{array}$ & $\begin{array}{c}\text { Antisocial } \\
\text { PP }\end{array}$ \\
\hline Tobacco use & $0.52^{* * *}$ & - & & & & & & & & & & \\
\hline Cannabis use & $0.57^{* * *}$ & $0.58^{* * *}$ & - & & & & & & & & & \\
\hline Ecstasy use & $0.27^{* * *}$ & $0.25^{* *}$ & $0.38^{* * *}$ & - & & & & & & & & \\
\hline Cocaine use & $0.33^{* * *}$ & $0.31^{* * *}$ & $0.49^{* * *}$ & $0.57^{* * *}$ & - & & & & & & & \\
\hline $\begin{array}{c}\text { Perceived } \\
\text { availability of } \\
\text { cocaine }\end{array}$ & $-0.26^{* * *}$ & $-0.26^{* * *}$ & $-0.35^{* * *}$ & $-0.22^{* * *}$ & $-0.24^{* * *}$ & - & & & & & & \\
\hline $\begin{array}{c}\text { Perceived } \\
\text { availability of } \\
\text { ecstasy }\end{array}$ & $-0.20^{* * *}$ & $-0.18^{* * *}$ & $-0.24^{* * *}$ & $-0.28^{* * *}$ & $-0.16^{* * *}$ & $0.75^{* * *}$ & - & & & & & \\
\hline Risk of cocaine use & $-0.13^{* * *}$ & $-0.15^{* * *}$ & $-0.22^{* * *}$ & $-0.29^{* * *}$ & $-0.33^{* *}$ & $0.08^{* *}$ & $0.07^{*}$ & - & & & & \\
\hline Risk of ecstasy use & -0.06 & $-0.08^{* *}$ & $-0.14^{* * *}$ & $-0.27^{* * *}$ & $-0.20^{* * *}$ & $0.06^{*}$ & $0.11^{* * *}$ & $0.63^{* * *}$ & - & & & \\
\hline Impulsiveness & $0.16^{* * *}$ & $0.19^{* * *}$ & $0.26^{* * *}$ & $0.28^{* * *}$ & $0.27^{* * *}$ & $-0.17^{* * *}$ & $-0.14^{* * *}$ & $-0.28^{* * *}$ & $-0.18^{* * *}$ & - & & \\
\hline Sensation seeking & $0.31^{* * *}$ & $0.28^{* * *}$ & $0.42^{* * *}$ & $0.33^{* * *}$ & $0.31^{* * *}$ & $-0.19^{* * *}$ & $-0.15^{* * *}$ & $-0.21^{* * *}$ & $-0.16^{* * *}$ & $0.43^{* * *}$ & - & \\
\hline Antisocial PP & $0.23^{* * *}$ & $0.25^{* * *}$ & $0.35^{* * *}$ & $0.38^{* * *}$ & $0.38^{* * *}$ & $-0.20^{* * *}$ & $-0.15^{* * *}$ & $-0.22^{* * *}$ & $-0.19^{* * *}$ & $0.60^{* * *}$ & $0.45^{* * *}$ & - \\
\hline Aggressive PP & $0.17^{* * *}$ & $0.21^{* * *}$ & $0.28^{* * *}$ & $0.31^{* * *}$ & $0.31^{* * *}$ & $-0.16^{* * *}$ & $-0.10^{* * *}$ & $-0.19^{* * *}$ & $-0.15^{* * *}$ & $0.55^{* * *}$ & $0.35^{* * *}$ & $0.75^{* * *}$ \\
\hline
\end{tabular}


of 0.61 . Regarding the predictions, personality traits was a predictor of the use of both legal substances $(\beta=0.46$; $p<.001)$ and cannabis $(\beta=0.15 ; p<$ .001), as well as personality patterns ( $\beta$ $=0.83 ; p<.001)$. Perceived availability of cocaine and ecstasy $(\beta=-0.08 ; p$ $<.01$ ) and perceived risk of sporadic cocaine and ecstasy use $(\beta=-0.27 ; p<$ .001) were significant in the prediction of psychostimulant use. Furthermore, the use of legal substances was significant in the prediction of cannabis use $(\beta=0.73$; $p<.001)$, which was in turn significant in the prediction of psychostimulant use $(\beta=0.39 ; p<.001)$. Finally, personality patterns were significant in the prediction of psychostimulant use $(\beta=0.30 ; p<$ .001). Thus, all of these variables explained $52.5 \%$ of the variance of psychostimulant use, with cannabis use and antisocial personality patterns being the variables that best predicted cocaine and ecstasy use, followed by perceived risk and perceived availability.

With the aim of analyzing whether there were differences according to gender in the prediction of psychostimulant use with the proposed model, we conducted a multi-group analysis to compare males and females. This model showed good fit $\left(\chi^{2} /\right.$ d.f. $=3.05 ; \mathrm{CFI}=0.958 ; \mathrm{GFI}=0.951 ; \mathrm{RMSEA}=$ 0.042; $\mathrm{AGFI}=0.929$ (Table 2).

The same model was assessed using multi-group analysis to assess differences by three age groups (14-17, 18-21, and $22-25)$. We observed that the fit was acceptable $\left(\chi^{2} /\right.$ d.f. $=$ 3.164; $\mathrm{CFI}=0.919 ; \mathrm{GFI}=0.914 ; \mathrm{RMSEA}=0.044 ; \mathrm{AGFI}=$ 0.891) (Table 2).

\section{Discussion}

According to the literature, we selected important variables related to psychostimulant use (cocaine and ecstasy) to design a predictive model with structural equation modeling analysis, capable to predict the use of these substances in youths aged 14 to 25.

The final model suggests that high scores in impulsiveness and sensation-seeking predict tobacco use, cannabis use, and drunkenness, similar to other studies (Hampson, Andrews, \& Barckely, 2008; Kubicka et al., 2001; Magid, MacLean, \& Colder, 2007). In turn, the use of these substances predicts psychostimulant use (cocaine and ecstasy) in line with what the Gateway Hypothesis states (Kandel, 2002). It should be pointed out that, as noted in previous studies such as that of Van Gundy \& Rebellon (2010) about the Gateway Hypothesis, the relationship between the use of substances such as alcohol and tobacco and the subsequent use of psychostimulants
Table 2. Goodness-fit-indices in the assessment of the model for the prediction of psychostimulant use by gender and age.

\begin{tabular}{ccccc}
\hline Indices & Acceptable values & All & Gender & Age \\
\hline$\chi^{2} / \mathrm{df}$ & $3<\chi^{2} / \mathrm{df}<5$ & 5.381 & 3.181 & 3.164 \\
$\mathrm{CFI}$ & $0.90<\mathrm{CFI}<0.97$ & 0.960 & 0.958 & 0.919 \\
$\mathrm{GFI}$ & $0.90<\mathrm{GFI}<0.95$ & 0.961 & 0.951 & 0.914 \\
$\mathrm{RMSEA}$ & $0.05<\mathrm{RMSEA}<0.08$ & 0.061 & 0.042 & 0.044 \\
$\mathrm{AGFI}$ & $0.85<\mathrm{AGFl}<0.90$ & 0.936 & 0.929 & 0.891 \\
\hline
\end{tabular}

CFI Comparative Fit Index

GFI Goodness-of-Fit Index

RMSEA Root Mean Square Error of Approximation

AGFI Adjusted Goodness-of-Fit Index.

is mediated by other factors in explaining the escalation of drug use.

In our study, high impulsiveness and sensationseeking also predict the presence of antisocial and aggressive personality patterns. As we pointed out at the introduction, antisocial personality pattern is characterized by the presence of impulsiveness (American Psychiatric Association, 2000), and aggressive personality pattern is considered by Millon and Davis (1998) as a subtype of antisocial personality pattern. Moreover, the presence of antisocial and aggressive patterns predicts cocaine and ecstasy use. This result goes in line with other studies carried out with users of these substances who seek treatment, which conclude that antisocial personality pattern is very common among cocaine users (López \& Becoña, 2006b). This is important because if we find those youths who have these personality patterns, we can prevent 
future problems with drug use that could lead to a future demand of treatment.

We can confirm that cannabis use and antisocial personality patterns in the model are the elements that best predict cocaine and ecstasy use, but there are two variables which, despite having less weight, are also significant in the prediction: Perceived availability of cocaine and ecstasy and perceived risk associated with the use of these substances.

If youths perceive that it is easy to access to a certain substance, this increases the likelihood of using this substance (Degendhart et al., 2008). The perception of negative consequences associated with cocaine and ecstasy use is also an important variable for predicting their use: If youths consider unlikely that they will suffer negative consequences of using cocaine and ecstasy they are more likely to use them. For example, in the case of cannabis, studies that examine prevalence of use over the years point to a clear relationship between its use and perceived risk (Degendhart et al., 2008).

If we focused on the differences between genders, we can say that even if the best predictors of psychostimulant use are cannabis use and antisocial personality patterns in both male and female, in females cannabis use and antisocial personality patterns have a greater weight than in males. The number of females who use cannabis (European Monitoring Centre for Drugs and Drugs Addiction, 2010), and have antisocial personality disorders (American Psychiatric Association, 2000) is less in comparison to males, so that the women that are cannabis users and have an antisocial personality pattern at the same time should be a focus of attention given the greater probability of using other drugs (as psychostimulants) in these women.

In conclusion, we present a model that predicts, using a small number of variables (personality traits, antisocial personality patterns, perceived availability, perceived risk, legal substance use, and cannabis use), lifetime cocaine and ecstasy use in people aged 14 to 25 . Until now we knew, as mentioned at the introduction, that all these variables were related to drug use. The present study indicates the way in which these variables predict cocaine and ecstasy use among youths and the relationship among them. Therefore, the model presented here can be seen as a useful tool for developing preventive strategies and for identifying those youths that are at risk for problems related to drug use. And as Brook, Pahl, \& Rubenstone pointed out: "There is a growing recognition of the importance of identifying trajectories that define the progression of substance use in particular subgroups users over a span of time." (pp. 35, 2008).

Among the limitations of the present study, we should mention the type of instruments we used for the assessment of the variables, the number of rejections that happened, and that it is a descriptive study. Carrying out longitudinal studies and the use of biological tests to determine substance use are two aspects that could be considered in future research. However, the sample size and the use of relevant variables in the prediction of psychostimulant use are two factors that lend robustness to the present study.

\section{Acknowledgment}

This research was supported by Xunta de Galicia, Servicio Galego de Saúde (SERGAS) by a cooperation agreement between Xunta de Galicia-SERGAS and University of Santiago de Compostela, Spain.

\section{Competing interest}

All authors declare they do not have conflict of interest.

\section{References}

American Psychiatric Association (2000). Diagnostic and statistical manual for mental disorders, 4th ed., revised text. Washington, D. C.: American Psychiatric Association.

Bachman, J. G., Johnston, L. D., O'Malley, P. M., \& Humphrey, R. $H$. (1988). Explaining the recent decline in marijuana use: Differentiating the effects of perceived risk, disapproval, and general lifestyle factors. Journal of Health and Social Sciences, 29, 92-112.

Bachman, J. G., O’Malley, P. M., Schulenberg, J. E., Johnston, L. D., Freedman-Doan, P., \& Messermith, E. E. (2008). The educationdrug use connection. Mahwah, NJ: Lawrence Erlbaum Associates, Publisher.

Becoña, E., López-Durán, A., Fernández del Río, E., Martínez, U., Fraga, J., Osorio, J., Arrojo, M., López, F., \& Domínguez, M. N. (2011). ¿Tienen una personalidad distinta los adolescentes consumidores de psicoestimulantes? Psicothema, 23, 552-559.

Belin, D., Mar, A. C., Dalley, J. W., Robbins, T. W., \& Everitt, B. J. (2008). High impulsivity predicts the switch to compulsive cocainetaking. Science, 320, 1352-1355. doi: 10.1126/science.1158136.

Brook, J. S., Pahl, K., \& Rubenstone, E. (2008). Epidemiology of addiction. In M. Galanter, \& H. D. Kleber (Eds.), The American psychiatric publishing textbook of substance abuse treatment (pp. 29-44). Arlington, VA: American Psychiatric Publishing.

Byrne, B. M. (2010). Structural equation modelling with AMOS. Basic concepts, applications, and programming. New York: Taylor \& Francis Group.

Calafat, A., Cajal, B., Juan, M., Mendes, F., Kokkevi, A., Blay, N.,...Duch, M. A. (2010). La influencia de las redes sociales en el uso y abuso de alcohol y drogas. Adicciones, 22, 147-154.

Chabrol, H., Ducongé, E., Casas, C., Roura, Ch., \& Carey, K. B. (2005). Relations between cannabis use and dependence, motives for cannabis use and anxious depressive and borderline symptomatology. Addictive Behaviors, 30, 829-840. doi:10.1016/j.addbeh.2004.08.027

Chung, T., \& Martin, C. (2011). Prevalence and clinical course of adolescent substance use and substance use disorders. In Y. 
Kaminer, \& K. C. Winters (Ed.), Clinical manual of adolescent substance abuse treatment (pp.1-23). Washington, D. C.: American Psychiatric Publishing, Inc.

Cohen, P., Chen, H., Crawford, T. N., Brook, J. S., \& Gordon, K. (2007). Personality disorders in early adolescence and the development of later substance use disorders in the general population. Drug and Alcohol Dependence, 88, S71-S84. doi:10.1016/j. drugalcdep.2006.12.012

Dawe, S., Gullo, M. J., \& Loxton, N. J. (2004). Reward drive and rash impulsiveness as dimensions of impulsivity: implications for substance misuse. Addictive Behaviors, 29, 1389-1405. doi:10.1016/j.addbeh.2004.06.004 http://www.ncbi.nlm.nih.gov/ pubmed?term=\%22Degenhardt\%20L\%22\%5BAuthor\%5D

Degendhart, L., Chiu, W. T., Sampson, N., Kessler, R. C., Anthony, J. C., Angermeyer, M., \& Wells, J. E. (2008). Toward a global view of alcohol, tobacco, cannabis, and cocaine use: findings from the WHO World Mental Health Surveys. PloS Medicine, 5, 1053-1067. doi:10.1371/journal.pmed.0050141

Dierker, L., Vesel, F., Sledjeski, E. M., Costello, D. \& Perrine, N. (2007). Testing the dual pathway hypothesis to substance use in adolescence and young adulthood. Drug and Alcohol Dependence, 87, 83-93.doi:10.1016/j.drugalcdep.2006.08.001

European Monitoring Centre for Drugs and Drugs Addiction (2010). The state of the drugs problem in Europe. Annual Report 2010. Retrieved from http://www.emcdda.europa.eu/attachements.cfm/ att_120104_EN_EMCDDA_AR2010_EN.pdf

Fantin, M. B. (2006). Perfil de personalidad y consumo de drogas en adolescentes escolarizados. Adicciones, 18, 285-292.

Fergusson, D. M., Boden, J. M., \& Horwood, L. J. (2008). The developmental antecedents of illicit drug use: Evidence from a 25-year longitudinal study. Drug and Alcohol Dependence, 96, 165-177. doi:10.1016/j.drugalcdep.2008.03.003

Forcada, R., Pardo, N., \& Bondia, B. (2006). Impulsividad en dependientes de cocaina que abandonan el consumo. Adicciones, $18,111-118$.

Hampson, S. E., Andrews, J. A, \& Barckley, M. (2008). Childhood predictors of adolescent marijuana use: Early sensation seeking, deviant peer affiliation, and social images. Addictive Behaviors, 33, 1140-1147. doi:10.1016/j.addbeh.2008.04.010

Hawkins, J. D., Catalano, R. F., \& Miller, J. Y. (1992). Risk and protective factors for alcohol and other drug problems in adolescence and early adulthood: Implications for substance abuse prevention. Psychological Bulletin, 112, 64-105.

Johnston, L. D., O’Malley, P. M., \& Bachman, J. G. (2001). Monitoring the Future national results on adolescent drug use: Overview of key findings, 2000. (NIH Publication No. 01-4923). Bethesda, MD: National Institute on Drug Abuse.

Johnston, L. D., O'Malley, P. M., Bachman, J. G., \& Schulenberg, J. E. (2009). Monitoring the Future National Results on Adolescent Drug Use: Overview of Key Findings, 2008. NIH Pub. No. 09-7401. Bethesda, MD: National Institute on Drug Abuse.

Kahler, C. W., Read, J. P., Wood, M. D., \& Palfai, T. P. (2003). Social environmental selection as a mediator of gender, ethnic, and personality effects on college student drinking. Psychology of Addictive Behaviors, 17, 226-234. doi: 10.1037/0893164X.17.3.226

Kandel, D., \& Faust, R. (1975). Sequence and stages in patterns of adolescent drug use. Archives of General Psychiatry, 32, 923-932.

Kandel, D. B. (Ed.) (2002). Stages and pathways of drug involvement. Examining the gateway hypothesis. Cambridge, NY: Cambridge University Press.

Keyes, K. M., Martins, S. S., \& Hasin, D. S. (2008). Past 12-month and lifetime comorbidity and poly-drug use of ecstasy users among young adults in the United States: Results from the National epidemiologic Survey on Alcohol and Related Conditions. Drug and Alcohol Dependence, 97, 139-149. doi:10.1016/j. drugalcdep.2008.04.001

Kilmer, J. R., Hunt, S. B., Lee, C. M., \& Neighbors, C. (2007). Marijuana use, risk perception, and consequences: is perceived risk congruent with reality? Addictive Behaviors, 32, 3026-3033. doi:10.1016/j.addbeh.2007.07.009

Korhonen, T., Huizink, A. C., Dick, D. M., Pulkkinen, L., Rose, R. J., \& Kaprio, J. (2008). Role of individual, peer and family factors in the use of cannabis and other illicit drugs: A longitudinal analysis among Finnish adolescent twins. Drug and Alcohol Dependence, 97, 33-43. doi:10.1016/j.drugalcdep.2008.03.015

Kubicka, L., Matejcek, Z., Dytrych, Z., \& Roth, Z. (2001). I0 and personality traits assessed in childhood as predictors of drinking and smoking behavior in middle-aged adults: a 24-year followup study. Addiction, 96, 1615-1628. doi: 10.1046/j.13600443.2001.961116158.x

Leung, K. S., Ben Abdallah, A., Copeland, J., \& Cottler, L. B. (2010). Modifiable risk factors of ecstasy use: Risk perception, current dependence, perceived control, and depression. Addictive Behaviors, 35, 201-208. doi:10.1016/j.addbeh.2009.10.003

López, A., \& Becoña, E. (2006a). Consumo de cocaina y psicopatología asociada: una revisión. Adicciones, 18, 161-196.

López, A., \& Becoña, E. (2006b). Patrones y trastornos de personalidad en personas con dependencia de la cocaina en tratamiento. Psicothema, 18, 577-582.

Martins, S. A., Storr, C. L., Alexandre, P. K., \& Chilcoat, H. D. (2008). Adolescents ecstasy and other drug use in the National Survey of Parents and Youth: The role of sensation-seeking, parental monitoring and peer's drug use. Addictive Behaviors, 33, 919933. doi:10.1016/j.addbeh.2008.02.010

Magid, V., MacLean, M. G., \& Colder, C. R. (2007). Differentiating between sensation seeking and impulsivity through their mediated relations with alcohol use and problems. Addictive Behaviors, 32, 2046-2061. doi:10.1016/j.addbeh.2007.01.015

Millon, T. (1994).Manual for the MCMI-III. Minneapolis: National Computer Systems.

Millon, T., Millon, C., Davis, R., \& Grossman, S. (1997). The Millon Adolescent Clinical Inventory (MACI). Minneapolis, MN: National Computer System. 
Millon, T., \& Davis, R. D. (1998). Trastornos de la personalidad. Más allá del DSM-IV [Personality disorders. Beyond the DSM-IV]. Barcelona: Masson.

Nace, E. P., Davis, C. W., \& Gaspari, J. P. (1991). Axis II comorbidity in substance abusers. American Journal of Psychiatry, 148, 118-120.

National Institute of Drug Abuse (2010). NIDA InfoFacts: High School and Youth Trends. Retrieved from http://www.nida.nih.gov/ infofacts/HSYouthtrends.html

Observatorio Español sobre Drogas (2009). Encuesta Estatal sobre Uso de Drogas en Estudiantes de Enseñanzas Secundarias (ESTUDES). Retrieved from http://www.pnsd.msc.es/Categoria2/observa/pdf/ Estudes2008.pdf

Oquendo, M. A., Baca-Garcia, E.,Graver, R.,Morales, M.,Montalban, \& V.,Mann, J. J. (2001). Spanish adaptation of the Barratt Impulsiveness Scale (BIS). The European Journal of Psychiatry, 15, 147-155.

Palmer, A., Montaño, J. J., \& Calafat, A. (2000). Predicción del consumo de éxtasis a partir de redes neuronales artificiales. Adicciones, 12, $29-41$.

Patton, J. H., Stanford, M. S., \& Barratt, E. S. (1995). Factor structure of the Barratt Impulsiveness Scale. Journal of Clinical Psychology, 51, 768-774. doi: 10.1002/1097-4679(199511)51:6<768::AIDJCLP2270510607>3.0.C0;2-1

Perez, J., \& Torrubia, L. (1986). Fiabilidad y validez de la escala de Búsqueda de Sensaciones (forma V). Revista Latinoamericana de Psicología, 18, 7-22.

Ruiz, M. A., Pardo, A., \& San Martín, R. (2010). Modelos de ecuaciones estructurales. Papeles del Psicólogo, 31, 34-45.

SPSS (2006). Structural equation modelling with Amos. Chicago, IL: SPSS.

Sussman, S., Skara, S., \& Ames, S. L. (2008). Substance abuse among adolescents. Substance Use \& Misuse, 43, 1802-1828. doi: $10.1080 / 10826080802297302$

Steinberg, L. (2010). A behavioral scientist looks at the science of adolescent brain development. Brain and Cognition, 72, 160-164. doi:10.1016/j.bandc.2009.11.003

Tabachnick, B. G., \& Fidell, L. S. (2007). Using Multivariate Statistics. Boston, MA: Allyn and Bacon.

Tarter, R. E., Kirisci, L., Mezzich, A., Cornelius, J. R., Pajer, K., Vanyukov, M. \& Clark, D. (2003). Neurobehavioral disinhibition in childhood predicts early age at onset of substance use disorder. American Journal of Psychiatry, 160, 1078-1085. doi:10.1016/j. drugalcdep.2003.07.004

Taylor, J. (2005). Substance use disorders and cluster B personality disorders Physiological, cognitive and environmental correlates in a college sample. The American Journal of Drug and Alcohol Abuse, 31, 515-535. doi: 10.1081/ADA-200068107

Van Gundy, K., \& Rebellon, C. J. (2010). A life-course perspective on the "Gateway Hypothesis". Journal of Health and Social Behavior, 51, 244-259. doi: 10.1177/0022146510378238
Verdejo-Garcia, A., Lawrence, A. J., \& Clark, L. (2008). Impulsivity as a vulnerability marker for substance-use disorders: review of findings from high-risk research, problem gamblers and genetic association studies. Neuroscience and Biobehavioral Reviews, 32, 777-810. doi:10.1016/j.neubiorev.2007.11.003

Verheul, R., \& van den Brink, W. (2000). The role of personality pathology in the etiology and treatment of substance use disorders. Current Opinion in Psychiatry, 13, 163-169.

Von Diemen, L., García, D., Costa, S., Maciel, C., \& Pechansky, F. (2008). Impulsivity, age of first alcohol use and substance use disorders among male adolescents: a population based casecontrol study. Addiction, 103, 1198-1205. doi: 10.1111/j.13600443.2008.02223.x

Zuckerman, M. (1979). Sensation seeking: Beyond the optimal level of arousal. Hillsdale, NJ: Erlbaum.

Zuckerman, M. (2007). The sensation seeking scale V (SSS-V): Still reliable and valid. Personality \& Individual Differences, 43, 13031305. doi: 016/j.paid.2007.03.021 